\title{
KOVIKO - et nyt bud på \\ "undervisningsbaseret forskning" i et tværfagligt digitalt lærings- og forskningsfællesskab?
}

\author{
Anders Blok, adjunkt, Sociologi, Kфbenhavns Universitet. \\ Martin Skrydstrup, Adjunct Professor and Assistant Curator, Wangari Maathai \\ Institute, University of Nairobi.
}

Ayo Wahlberg, postdoc, Antropologi, Københavns Universitet.

\begin{abstract}
Med stigende fokus på øget tværfaglighed og digitalisering i undervisningen på Københavns Universitet undersøger vi i denne artikel hvilke betingelser, der skal til, for at tværfaglighed og digitalisering rent faktisk kan omsættes til læringsudbytte? Det gør vi ved at reflektere over hoilke didaktiske komponenter, der har været virksomme i et nyligt afholdt, tværfagligt kursus: KOrtlægning af VIdenskabelige KOntroverser (KOVIKO). Vi identificerer tre vigtige komponenter som afgørende for de opnåede læringsmæssige resultater: Socialisering til et nyt fagligt fxllesskab; internettet som omdrejningspunkt og oplæring til tværfaglige læringsindsatser. I konklusionen fremhæver vi det potentiale, som ligger i brug af digitale metoder og platforme som et fagligt integrerende element $i$ "undervisningsbaseret forskning".
\end{abstract}

\section{Introduktion: Lærings- og forskningsfællesskaber i en digital tidsalder}

Som "yngre" ansatte ved det Samfundsvidenskabelige Fakultet på Københavns Universitet (KU), med såvel forsknings- som undervisningsopgaver i vores daglige arbejde, følger vi selvsagt tidens diskussioner om forskningsbaseret undervisning tæt. Med denne formidlingsartikel vil vi dog henlede opmærksomheden på diskussionens mindst lige så vigtige, men betydeligt mere oversete "tvilling": Nemlig muligheden for at praktisere sin undervisning som forskning, altså i form af "undervisningsbaseret forskning". Nærmere bestemt ønsker vi at dele og reflektere over nogle erfaringer med at omdanne et tværfagligt klasselokale til et velfungerende læringsog forskningsfællesskab orienteret mod fælles faglige målsætninger og integreret gennem brugen af en fælles digital platform. Vores gennemgående pointe vil være, 
at undervisningsbaseret forskning - under de rette former og vilkår - kan medvirke til at give et højt læringsudbytte for de studerende.

Baggrunden for disse refleksioner er vores personlige erfaringer med i fællesskab at undervise i faget KOrtlægning af VIdenskabelige KOntroverser (KOVIKO), udviklet som et nyt og eksperimentelt overbygningskursus i samarbejde mellem de antropologiske og sociologiske institutter på KU. Kurset er, kort fortalt, en fokuseret og projektdrevet introduktion til det tværfaglige forskningsfelt, som går under betegnelsen videnskabs- og teknologistudier (STS), og som vi hver især arbejder indenfor. Med kurset lægges vægten på de studerendes evner til at omsætte feltets teorier i konkrete undersøgelser. I grupper på to eller tre undersøger og kortlægger de studerende en selvvalgt kontrovers, hvor divergerende videnskabelige opfattelser udspiller sig i et offentligt rum (f.eks. genmodificerede organismer, klima, vacciner, osv.). Metodisk og didaktisk sker kortlægningen gennem brug af nye digitale værktøjer, der sætter de studerende i stand til at systematisere, analysere og til sidst grafisk visualisere store mængder af information.

KOVIKO blev udviklet som led i KU's satsning på at styrke universitetets pædagogiske profil gennem projektet "Den gode uddannelse", og kursets opbygning resonerer da også tydeligt med dette projekts overordnede fokus på øget tværfaglighed og digitalisering i undervisningen. ${ }^{1}$ Efter vores opfattelse giver denne baggrund forøget anledning til at spørge, under hvilke betingelser tværfaglighed og digitalisering rent faktisk kan omsættes til læringsudbytte for de studerende? Dette så meget desto mere som at buzzwords a la digitalisering i sig selv indeholder en mængde indbyggede faldgruber og i praksis nemt kan blive en fernis, der skjuler snarere end afhjælper mere grundlæggende pædagogiske rammeproblemer.

Vores primære analytiske svar på dette spørgsmål vil som antydet være, at det med KOVIKO lykkedes at skabe et velfungerende lærings- og forskningsfællesskab - ikke blot i selve klasselokalet, men også som et forestillet fællesskab med bredere ringe ud i tid og rum. Vi vil løbende i artiklen uddybe denne pointe og hermed prøve at vise, hvilke didaktiske komponenter, der efter vores opfattelse har været virksomme: Socialisering af de studerende til et nyt fagligt fællesskab; internettet som omdrejningspunkt og oplæring til tværfaglige læringsindsatser. Vi støtter her vores fortolkninger på Changs (2005) diskussion af sine erfaringer med at omdanne et standard bachelorkursus til et levende og professionelt forskningsfællesskab samt til Healeys (2005)

\footnotetext{
${ }^{1} \mathrm{Vi}$ vil gerne benytte lejligheden til at rette en varm tak til "Den gode uddannelse", uden hvis økonomiske og moralske støtte KOVIKO-kurset ikke var blevet realiseret. Vi ønsker også at takke alle på KOVIKO-holdet, der hver på deres måde bidrog til at gøre projektet til en succes: Studieleder Helle Bundgaard, fakultetsbibliotekar Tina Buchtrup Pipa, it-ansvarlig Steen Kelså, pædagogisk konsulent Rikke von Müllen, uv- assistent Jacob Ørmen, samt vore studenter Claudia Maria Bagge-Petersen og Kristoffer Albris.
} 
diskussion af "undersøgelsesbaseret læring" ('inquiry-based learning'). Vores erfaringer ligger særligt i forlængelse af Changs, ligesom hans tanker har fungeret som didaktisk inspiration i den praktiske tilrettelæggelse af vores undervisningsforløb.

\section{KOVIKO: Socialisering til et nyt fagligt fællesskab}

Første runde af KOVIKO-kurset blev afviklet i efteråret 2011 med et hold bestående af godt 20 studerende hvoraf to tredjedele var fordelt ligeligt mellem antropologi og sociologi, mens resten kom fra naturvidenskab og humaniora. Vi var fra starten meget bevidste om aktivt at skabe et fælles læringsrum baseret på gensidig anerkendelse af de respektive fag, som var repræsenteret i klasselokalet. Som undervisere gjorde vi det samtidig hurtigt klart, at de studerendes indsats på KOVIKO var at sidestille med en egentlig tværfaglig forskningsproces, og at de derfor burde betragte sig selv som medproducenter af ny, forskningsmæssig viden indenfor STS-feltet. I tråd med Chang og Healey var det således vores udgangspunkt, at "de studerende får mest ud af forskning, når de selv er involveret i forskning", som Healey udtrykker $\operatorname{det}(2005: 1)$.

Vi understregede endvidere, at en selvforståelse som "forskeraspirant" ikke behøver at være nær så uopnåelig, som den måske ved første øjekast kan fremstå for studerende. Det gjorde vi bl.a. gennem en holdlæsning af netop Chang, hvis tekst understreger, at forskningsdyder som "ekspertise" og "originalitet" i bund og grund er relative: Ved man mere end sine omgivelser, er man ekspert, og det er helt okay at genopfinde hjulet, hvis ingen i ens fællesskab har ét! Forskning sigter mod produktionen af $n y$ viden, og Changs diskussion hjalp os til at sandsynliggøre, at der er kontinuitet snarere end brud mellem de studerendes egne undersøgelser på KOVIKOholdet og den til enhver tid eksisterende forskningsfront indenfor STS-feltet.

Hele undervisningsforløbet var som nævnt struktureret omkring det formål, at de studerende i grupper gennemførte en selvstændig undersøgelse af en videnskabelig kontrovers primært gennem brug af digitale metoder. Dette ud fra et STS-fagligt perspektiv, der tilsiger, at videnskabelige kontroverser præges af - og selv er med til at forme og forandre - deres kulturelle, sociale og politiske kontekster på komplekse måder, ofte i et samspil mellem lokale og globale aktører, netværk og processer (Venturini, 2010). Konkret udmøntede undersøgelserne sig i at grupperne udarbejdede en (simpel) hjemmeside med det formål at kortlægge, analysere og visualisere det omstridte samfundsmæssige domæne, hvori videnskaben er indlejret. Det kunne f.eks. dreje sig om den kontrovers, der udspiller sig omkring såkaldte "klimaskeptikere", eller - med et faktisk eksempel fra holdet - om den måde danske, russiske og cana- 
diske geologer nutidigt strides om retten til at definere havbunden under Arktis i regi af FN's Havretskommission. ${ }^{2}$

For os som undervisere handlede det om hurtigt at få sporet de studerende ind på den faglige tankegang med henblik på, at de efter blot et par uger på kurset selv ville være i stand til at udvælge sig en spændende STS-case til det videre projektarbejde. I den sammenhæng udnyttede vi det forhold, at KOVIKO-kurset er udviklet med tæt inspiration fra et eksisterende didaktisk koncept, hvis pioner er den kendte franske videnskabsantropolog Bruno Latour. På Latours foranledning er der således siden midten af 2000'erne blevet undervist i videnskabelig kontroverskortlægning på en række europæiske og amerikanske eliteuniversiteter, inklusiv Sciences Po i Paris og MIT i Cambridge, Massachusetts. Tilsammen udgør disse uddannelsesinstitutioner et transnationalt netværk, som bindes sammen via en digital infrastruktur. ${ }^{3}$

Konkret betød det, at vi straks fra start kunne præsentere vores studerende for et sæt af eksisterende studentergenererede projekter og hjemmesider, der antog karakter af dét, vi med Kuhn (1962) kan kalde "paradigmatiske cases". For de studerende tjente disse cases dels som introduktion til kursets didaktisk-digitale format; dels som kilde til emnemæssig inspiration og dels som en praktisk bevisførelse for, at man som studerende faktisk kan levere et substantielt bidrag til dette lærings- og forskningsfællesskab. De studerende blev hermed inviteret indenfor i et allerede eksisterende (virtuelt) fagmiljø, og trods den store studiemæssige spredning er det vores vurdering, at det herigennem lykkedes at gøre socialiseringsprocessen ind i det "eksklusive" STS-fællesskab af kontroverskortlæggere attraktiv for de studerende.

Undervejs i de studerendes gruppeprojektarbejde var det vigtigt for os som undervisere at signalere, at der var tale om en åben undersøgelsesproces drevet frem af en kollektiv interesse og undren, og hvor ingen sad inde med svarene på forhånd. På den måde søgte vi at skabe et inkluderende læringsrum, hvor et skarpt skel mellem videnskabelig ekspertise (inklusiv undervisernes) og de studerende blev erstattet af ideen om fælles indvundne forskningsfærdigheder. Dette var ikke mindst vigtigt i det praktiske arbejde med kursets digitale redskaber, hvor de studerende hurtigt indså, at deres medstuderendes erfaringer kan være lige så værdifulde bidrag til egen læring som den "kanoniserede" ekspertviden.

Samtlige studerende endte med at gennemføre kurset på en fagligt meget tilfredsstillende måde, hvilket bl.a. afspejlede sig i et højt karaktergennemsnit. Ved fagets afsluttende minikonference, hvor studentergrupperne præsenterede deres kontrovers-

\footnotetext{
${ }^{2}$ En samlet oversigt over de studerendes projekter, samt links til deres hjemmesider, kan findes på KOVIKO-kursets hjemmeside: http://cms.ku.dk/samf-sites/antro-sites/koviko/.

${ }^{3}$ På engelsk hedder kurset Mapping Controversies, og det udspringer fra Sciences Po-universitetet, hvor Latour er professor. Se evt. kursets hjemmeside: http://www.demoscience.org/.
} 
hjemmesider for hinanden, stod det klart for alle, at de havde formået at vende udfordringen med undervisningsbaseret forskning i et tværfagligt miljø til et højt kollektivt læringsudbytte. Samtidig fortsatte det sociale læringsfællesskab også efter kursets formelle ophør: På initiativ af de studerende selv blev der arrangeret en studietur til Paris, som fandt sted i januar 2012, med henblik på at opleve Latour og hans kollektiv af kontroverskortlæggere på Sciences Po.

\section{Læring med internettet som omdrejningspunkt?}

Computeren udgør som antydet det primære didaktiske redskab på KOVIKOkurset. Udgangspunktet er her den iagttagelse, at mange videnskabelige diskussioner nutidigt (også) udspiller sig i digitale offentligheder medieret gennem ekspertorganisationers hjemmesider, forskningsdatabaser (a la Google Scholar), nyhedssider, blogs osv. Ideen med KOVIKO er kort sagt at udnytte dette forhold til at studere videnskabelige kontroverser $p a ̊$ og med internettet. Til det formål introduceres de studerende til en række digitale redskaber, der bl.a. sætter dem i stand til at opspore hyperlinknetværk mellem organisationer på nettet samt at benytte strategiske søgeord til at undersøge organisationers opslutning bag bestemte videnskabelige påstande. ${ }^{4}$

På denne måde placerer KOVIKO-kurset sig midt i en malstrøm af sociale forandringsprocesser på og uden for universiteterne centreret omkring øget digitalisering af viden. Disse digitaliseringsprocesser har store og åbenlyse konsekvenser for den måde forskning organiseres, opsøges og benyttes på; og dette er om noget tydeligt i den måde studerende i dag tænker omkring og tilegner sig forskningsmæssig og anden viden. For de fleste af nutidens studerende vil det forekomme indlysende, at de konstant må navigere i en overflod af mere eller mindre usikker eller troværdig (videnskabelig) viden. Eller som sociologen Andrew Abbott (2009:7) illustrerer pointen: For nutidens studerende betyder et "indeks" simpelthen et digitalt søgeord; emne-registret bagerst i en bog forekommer dem abstrakt.

Blandt universitetsundervisere forstås disse forandringsprocesser ofte næsten udelukkende negativt. Vi kender alle klagesangene: De studerende har mistet sansen for bøgernes sande intellektualitet; de udviser en overfladisk zappermentalitet; de forveksler Wikipedia med den højeste sandhed samt den decideret plagierende variant, der består i "Google-opgaver", hvor studerende har "cuttet" og "pasted" væsentlige dele af indholdet fra nettet. Selvfølgelig er der behov for kritisk refleksivitet i omgangen med digitale vidensformer. Ophøjet til en slags kulturel berøringsangst overfor det digitale er problemet imidlertid det dobbelte, at man som underviser dels

\footnotetext{
${ }^{4}$ Specifikt går disse softwareredskaber under de respektive navne Issue Crawler og Lippmanian Device. Begge redskaber er udviklet af Richard Rogers, professor i digitale medier ved universitetet i Amsterdam. De er tilgængelige fra Rogers' metodehjemmeside: www.digitalmethods.net.
} 
risikerer at øge afstanden til de studerendes hverdag, dels går glip af en række nye metodemæssige ressourcer til indhentning, bearbejdning og analyse af viden.

Ét helt centralt formål med KOVIKO er her netop at afsøge mulighederne for at nyttiggøre internettet som lærings- og forskningsredskab. Som én af pionererne indenfor den samfundsvidenskabelige brug af digitale metoder, Richard Rogers, udtrykker sit (let provokerende) budskab: "search is research", digital informationssøgning er forskning (se Rogers, 2009). Eller rettere, det kan det blive givet oplæring i den reflekterede brug af en række digitale teknikker og redskaber til besvarelse af faglige spørgsmål. Kontroverskortlægning ved hjælp af digitale metoder er her netop andet og mere end "blot" informationssøgning, fordi det forskningsmæssige fokus består i at undersøge, hvordan videnskabelig viden cirkuleres og forbruges offentligt via internettets hjemmesider for herigennem at forstå de uenigheder, forbindelser og symbolske samlingspunkter, der udgør en kontrovers (Venturini, 2010; Højsgaard, 2011).

Konkret foregik læringen ved at de studerende under vejledning eksperimenterede med de digitale redskaber i projektgrupperne med henblik på at omsætte dem til en indløsning af deres fagligt motiverede STS-spørgsmål. Som undervisere var det vores klare indtryk, at de studerende tog imod chancen for at bruge deres digitale færdigheder til faglige formål med stor entusiasme. For de fleste var arbejdet med de digitale metoder og muligheden for at omsætte sine undersøgelser i et digitalt format i form af en hjemmeside en selvstændigt motiverende faktor i deres tilvalg af kurset. Samtidig endte mange med en kritisk-konstruktiv indstilling til såvel muligheder som begrænsninger ved digitale metoder. På den måde bidrog kurset til en mere generel bevidsthed om datakvalitet og -validitet i socialvidenskabelig forskning.

Overordnet er det således vores erfaring, at centrering af undervisningsforløbet omkring digitale metoder besad klare dimensioner af velkommen fornyelse og faglig kreativitet for de studerende. Her tilbød det eksisterende lager af kontrovershjemmesider en art fælles målestok, der inspirerede til at eksperimentere og på egen hånd opsøge nye færdigheder, både indenfor og på tværs af projektgrupper. Som format for de studerendes produkter har hjemmesiden yderligere den fordel, at den gør det muligt at udstrække det faglige fællesskab ikke blot i rummet - gennem de transnationale forbindelser - men også i tid, fordi tidligere studenterårganges projekter er digitalt tilgængelige for nye studerende. På længere sigt er det vores hensigt, at fællesskabet af kontroverskortlæggere på denne vis kan tjene til at formidle viden mellem generationer af studerende på KU. I lighed med Chang (2005) er det her vores påstand, at en sådan kontinuitet over tid er afgørende for de studerendes motivation, fordi deres indsats på den vis sikres et relevant publikum; noget der sjældent er tilfældet med en traditionel eksamensopgave. 


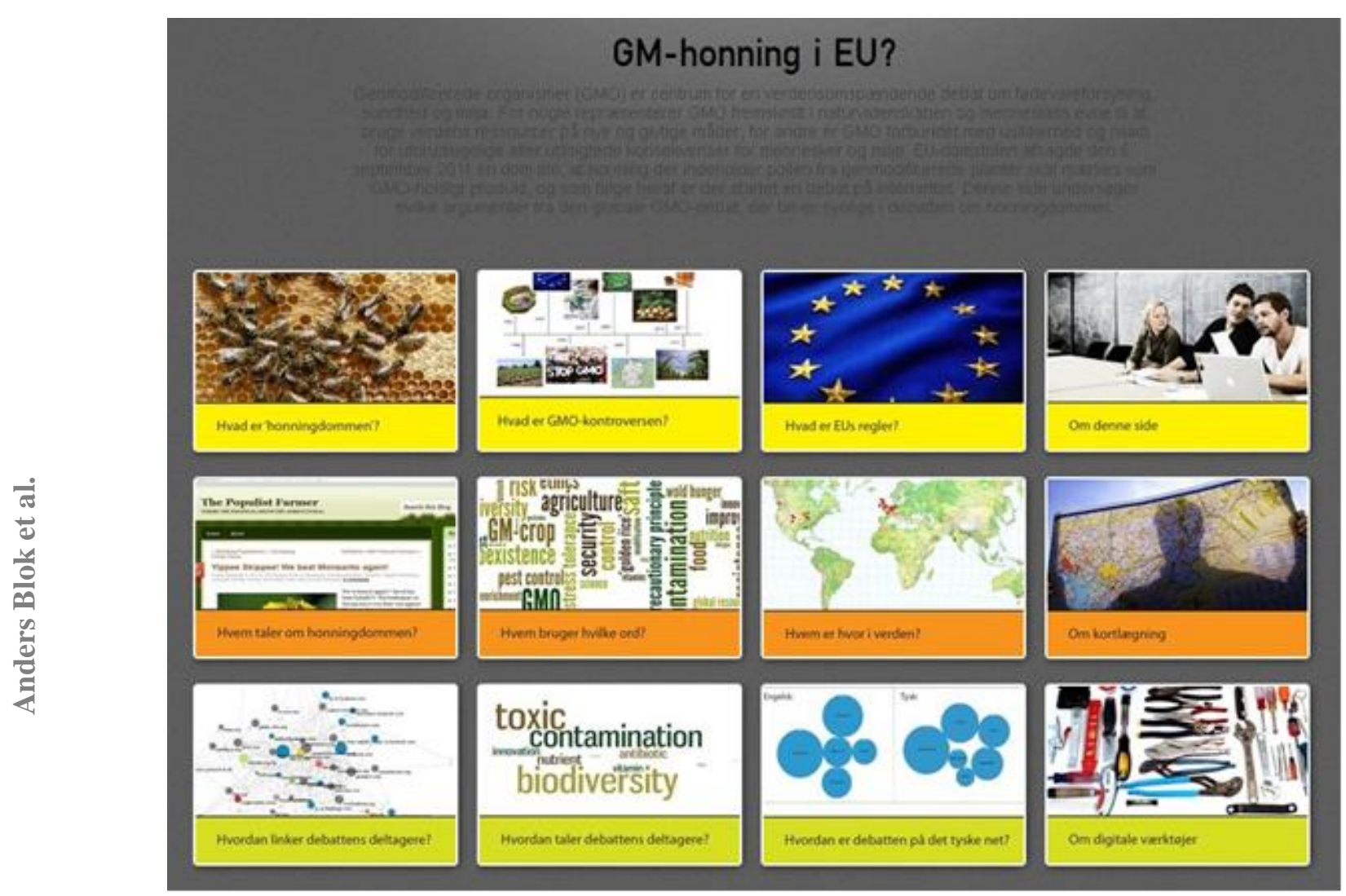

Figur 1. Forside af en KOVIKO projekthjemmeside.

\section{Oplæring til tværfaglige lærings- og forskningsindsatser?}

I mange universitære sammenhænge er tværfaglighed blevet et mantra, uden at det af den grund er særlig tydeligt, hvad det indebærer, eller præcist hvordan det tænkes at øge kvaliteten af viden, forskning og uddannelse. Ofte har man indtryk af, at tværfaglighed praktiseres som en art laveste faglige fællesnævner, hvor kriterierne for kvalitet i vidensproduktionen er vage og flydende. Samtidig må man konstatere, at udviklingen af velfungerende, tværfaglige undervisningsformater halter noget efter de udviklinger, der trods alt er sket i forskningssammenhænge. Det er i hvert fald tilfældet i vores egen institutionelle virkelighed, hvor alene den "nære" tværfaglighed mellem antropologer og sociologer, som KOVIKO bygger på, repræsenterer en pædagogisk nyskabelse.

Selv om vores erfaringer fra KOVIKO-kurset næppe bør generaliseres for bredt, så mener vi os ikke desto mindre i stand til, på denne baggrund, at bidrage kvalificeret til en diskussion om, hvornår og hvordan tværfaglighed i undervisningen giver didaktisk mening. Vores påstand kan her opsummeres på kort formel: Tværfaglighed i undervisningen synes at fungere godt, når de studerende i grupper skal løse konkrete opgaver af forskningslignende karakter, hvortil der gives relativt klare og normgivende modeller for god praksis (Kuhns "paradigmatiske cases"), og hvor formatet er relativt bundet (en simpel hjemmeside). 
Der er givetvis flere specifikke elementer ved KOVIKO-kurset, der gør, at det her lykkedes at omdanne et tværfagligt klasselokale til et lærings- og forskningskollektiv; nogle af dem, især de digitale metoder, har vi allerede været inde på. Centralt i denne sammenhæng er desuden det forhold, at kurset er bygget op omkring et forskningsfelt, STS, som er iboende disciplinoverskridende i sin tilgang. Kort fortalt består megen STS-forskning $i$, at man med samfundsvidenskabelige metoder (interviews, observationer, statistik, tekstanalyse osv.) studerer produktionen af naturvidenskabelig og/eller teknisk viden, instrumenter og produkter. På den måde inkarnerer forskningsfeltet en ambition om at bevæge sig på tværs af grænserne mellem dét, C. P. Snow (1959/1998) kaldte for "de to kulturer" af natur- og kulturvidenskab.

Konkret betød det, at STS-litteraturen på KOVIKO-kurset tilbød de studerende et "tredje sted" ved siden af eksisterende disciplinorienterede fagidentiteter. Det var i første omgang vigtigt for de antropologi- og sociologistuderende, som hver især kunne genkende væsentlige elementer af "deres" metoder og teorier i kurset, uden at de af denne grund helt kunne domesticere de fælles nye STS-faglige udfordringer. I anden omgang var det helt afgørende for den mere "fjerne" tværfaglighed, som bestod i, at studerende fra naturvidenskab og humaniora blev inviteret indenfor i et, trods alt, socialvidenskabeligt defineret læringsrum. Her tilbød den skarpe fokusering på nogle få, centrale STS-tilgange en art "genvej", der eksplicit undlod at forpligte de studerende på andre, og tungere, socialvidenskabelige fagtraditioner.

Den primære tværfaglige praksis på KOVIKO-holdet bestod selvsagt i de studerendes gruppebaserede projektarbejde; det var her - i dialogen mellem de studerende i og uden for klasselokalet - at den egentlige værdi af tværfaglig undervisning kunne vise sig. Her må vi som undervisere medgive, at ambitionerne ikke helt blev indfriet i første runde af KOVIKO-kurset. Studentersammensætningen tillod ganske enkelt ikke den nødvendige fagdiversitet, der skulle til for, at alle studerende kom til at opleve et egentligt tværfagligt projektforløb. For nogle grupper kom tværfagligheden derfor mest til at bestå i det "forestillede" møde med en for dem esoterisk gren af videnskaben (havbundsgeologi, intelligenspsykologi, trafikøkonomi osv.), i takt med, at de kortlagde det netværk af sociale forgreninger, som denne videnskab er spundet ind $i$.

For nogle gruppers vedkommende var der imidlertid tale om et genuint tværfagligt projektsamarbejde. Og her var erfaringen, at dette samarbejde gav anledning til ekstra læringsgevinster. Eksempelvis kortlagde én gruppe bestående af en antropolog, en sociolog og en biolog de videnskabelige, juridiske og politiske aspekter af den kontrovers, der udspillede sig efter, at EU-domstolen i efteråret 2011 havde fastslået, at honning med spor af GMO skal markedsføres som en "GMO-holdig" fødevare. 5

\footnotetext{
${ }^{5}$ Hjemmesiden kan besøges her: http://gmhonning-koviko.posterous.com/.
} 
Selv om fokus lå på fortolkningen af dommen blandt miljøaktivister, honningproducenter, politikere og andre, så var det selvsagt afgørende for projektets kvalitet, at gruppen havde adgang til biologisk ekspertise om GMO-debatten. Samme pointe gælder også den anden vej: Gruppen har efterfølgende formået at integrere deres hjemmeside som element i den videnskabsteoretiske undervisning på KU's Biovidenskabelige Fakultet med henblik på, at de studerende her kan lære om de sociale aspekter af deres naturvidenskab.

Alt i alt vil vi hævde, at de studerende qua KOVIKO-kursets tværfaglige undervisningsforløb - og med de ovennævnte forbehold in mente - ikke blot har lært noget substantielt om vores videnskabelige kultur men tillige har opnået en konkret erfaring med, hvad tværfaglig læring og forskning indebærer i praksis.

\section{Afrunding: Drømmen om en fakultetsovergribende lærings- og forskningsplat- form}

Vores formål med denne artikel har været at viderebringe og reflektere over nogle positive erfaringer med at omdanne et tværfagligt klasselokale til et velfungerende lærings- og forskningsfællesskab. Vi har undervejs forsøgt at fremhæve nogle af de didaktiske komponenter, som efter vores opfattelse har været afgørende for, at KOVIKO-eksperimentet lykkedes som undervisningsbaseret forskning: Socialiseringen af de studerende som medproducenter af ny forskningsmæssig viden; centreringen omkring et eksisterende pædagogisk format og fagmiljø af transnationalt tilsnit; vægten på digitale metoder og hjemmesiden som fælles produktformat der videreføres over tid samt betoningen af tværfagligt projektsamarbejde orienteret i forhold til en normgivende model for god praksis. Kombinationen af disse komponenter, hævder vi, har i dette tilfælde virket klart læringsfremmende for de studerende.

Vores erfaringer ligger her i tæt forlængelse af Changs (2005) og Healeys (2005) pointer $\mathrm{i}$ forhold til den faglige motivation, de studerende kan opnå, når de inviteres ind $\mathrm{i}$ et lærings- og forskningsfællesskab med kontinuitet i tid og rum. Her oplever de studerende, at de med deres færdigheder faktisk kan levere bidrag til en aktuel forskningsfront, som er på omdrejningshøjde med den "kanoniserede" ekspertise. Modsat Chang, som arbejder i et tekstligt format (antologien), så har vi understreget de muligheder der ligger i hjemmesiden som vidensprodukt, idet den virtuelle database af studerendes hjemmesider tjener som markør for det faglige fællesskab. I tillæg til Healey har vi endvidere betonet, at praktisering af undervisningsbaseret forskning med fordel kan ske ikke blot i disciplinære men også i tværfaglige, læringsrum.

For os som undervisere ligger det lige for at ville videreføre, og udbygge, disse erfaringer over tid. Konkret planlægger vi at afholde anden runde af KOVIKO-kurset i efteråret 2012, denne gang $i$ et intensivt format, som vi vurderer passer godt til kur- 
sets vægt på projektarbejdet. Endvidere ønsker vi at udvikle kurset i nye pædagogiske retninger og herunder at arbejde målrettet med de elementer af genuin tværfaglighed, hvor planerne ikke helt blev indfriet i første runde. Dette kræver en målrettet indsats i forhold til rekruttering af studerende fra samtlige fakulteter på KU. Vores ambition er således, at KOVIKO med tiden kan udvikle sig til en egentlig fakultetsovergribende lærings- og forskningsplatform på KU, som tjener til at binde studerende sammen på tværs af faggrænser, nationer og generationer.

I et bredere perspektiv er det tillige vores forhåbning, at de erfaringer, vi har gjort os med dette didaktiske eksperiment, kan have motiverende afsmitning i andre sammenhænge. Foruden det tværfaglige islæt vil vi her især fremhæve det potentiale, som efter vores opfattelse ligger i den kritisk reflekterede brug af digitale metoder og platforme som et fagligt integrerende element i undervisningen. Vores erfaring fra KOVIKO tilsiger, at computeren kan fungere som et stærkt kollektivt omdrejningspunkt, der tillader de studerende at koble sig til et grænseoverskridende fagligt fællesskab. Her er det efter vores opfattelse afgørende, at vi som universitetsundervisere formår at se "nettet" som andet og mere end en trussel mod vores videnskultur og i stedet begynder at betragte det som en central ressource i en akademisk forskningsog undervisningspraksis for, $\mathrm{i}$, og om en digital tidsalder. I denne tid, hvor "forskningsbaseret undervisning" som koncept, praksis og universitært "brand" er til debat, kan KOVIKO her levere ét bud på, hvordan en "undervisningsbaseret forskning" kunne se ud på fremtidens KU.

Anders Blok er adjunkt og postdoc ved Sociologisk Institut, Københavns Universitet, med et forskningsprojekt om storbyers rolle i den globale klimapolitik. Ud over KOVIKO underviser han på diverse overbygningskurser på sociologiuddannelsen, senest omkring nyere teoriudviklinger $i$ fransk pragmatisk sociologi. Fagligt følger han diskussioner om videnskabs- og teknologistudier (STS) tæt, med en særlig interesse for brugen af digitale metoder $i$ sociologisk forskning og undervisning.

Martin Skrydstrup var initiativtager til og projektleder for KOVIKO under sin ansættelse som postdoc ved Institut for Antropologi, Københavns Universitet. Fra 2012 arbejder han med at udvikle et nyt curriculum på Wangari Maathai Institute for Peace and Environmental Studies på University of Nairobi $i$ Kenya, med udgangspunkt $i$ nobelpristagerens vision om at oversætte akademisk viden om bxredygtig naturressourceforvaltning til beslutningstagere og praktikere. Tidligere har han forelæst på SciencePo i Paris og undervist i antropologi på Columbia University $i$ New York, hoorfra han har sin ph.d.-grad.

Ayo Wahlberg er cand.scient.soc., ph.d. og postdoc ved Institut for Antropologi på Københavns Universitet. Ayo forsker i nye reproduktive teknologier $i$ Kina og underviser i medicinsk antropologi samt KOVIKO med en interesse for udvikling af nye former for undervisningsbaseret forskning. 


\section{Litteratur}

Abbott, A. (2009). The Future of Knowing. Paper til University of Chicago Alumni Association. http://home.uchicago.edu/ aabbott/Papers/futurek.pdf

Chang, H. (2005). Turning an undergraduate class into a professional research community. Teaching in Higher Education 10(3), s. 387-393.

Healey, M. (2005). Linking research and teaching exploring disciplinary spaces and the role of inquiry-based learning. I Barnett, R. (red.) Reshaping the University: New Relationships between Research, Scholarship and Teaching. Maidenhead: McGraw-Hill/Open University Press, s. 30-42.

Højsgaard, L. (2011). Kontrovers-kortlægning som redskab. Forskerforum, No. 250, Dec. 2011, s. 22-23.

Kuhn, T. (1962). The Structure of Scientific Revolutions. Chicago: University of Chicago Press.

Rogers, R. (2009). The End of the Virtual: Digital Methods. Amsterdam: University of Amsterdam.

Snow, C. P. (1959/1998). The Two Cultures. Cambridge: Cambridge University Press.

Venturini, T. (2010): Diving in magma: how to explore controversies with actornetwork theory. Public Understanding of Science 19(3), s. 258-273. 